\title{
Pengaruh Bahan Pengemas dan Lama Simpan Terhadap Kualitas Fisik Wafer Ransum Komplit Berbasis Limbah Pelepah Salak
}

\section{The Effect of Packaging Material and Storage Rate on Physical Quality of Complete Feed Wafer Based Waste Production of Salacca sumatrana Becc}

\author{
Rikardo Silaban $^{1)}$, Sutan Pulungan ${ }^{2)}$, Muhammad Muhaidi Sihombing ${ }^{1)}$ \\ ${ }^{1)}$ Program Studi Peternakan, Universitas Graha Nusantara Padang Sidempuan, Sumatera Utara \\ ${ }^{2)}$ Program Studi Agribisnis, Universitas Graha Nusantara Padang Sidempuan, Sumatera Utara \\ Corresponding Author: rikardo.silaban@ymail.com
}

\begin{abstract}
Diterima : 07 Februari 2020
Disetujui : 27 Februari 2020

Diterbitkan : 29 Februari 2020
\end{abstract}

\begin{abstract}
Abstrak: $\quad$ Produksi limbah tanaman salak Sidempuan dapat mencapai 31-43\% per tahun atau setara dengan 26o-310 ton per tahun. Produksi biomassa limbah tersebut dapat berpotensi dijadikan sebagai sumber pakan alternatif untuk ternak rumiansia seiring dengan ketersediaan lahan untuk penyediaan hijauan makanan ternak yang semakin minim. Penelitian bertujuan untuk mengetahui pengaruh perbedaan lama simpan dan jenis pengemas terhadap kualitas fisik wafer ransum komplit. Penelitian ini dilaksanakan di laboratorium Industri Makanan Ternak, Fakultas Pertanian Universitas Graha Nusantara Padang Sidempuan dan Kelompok Tani Desa Satahisaoloan. Penelitian menggunakan rancangan acak lengkap pola faktorial $4 \times 3$ dengan 2 faktor (bahan pengemas dan lama penyimpanan) dan 3 ulangan. Parameter penelitian meliputi kualitas fisik wafer yakni bobot wafer, kadar air, kerapatan wafer dan daya serap air. Hasil penelitian menunjukkan bahwa bahan pengemas berbeda mempengaruhi kualitas fisik pakan wafer. Sedangkan, faktor penyimpanan tidak mempengaruhi performa fisik wafer. Dapat disimpulkan bahwa interaksi bahan pengemas kantong plastik dengan umur simpan 7 hari memberi performa fisik wafer yang lebih baik.
\end{abstract}

Kata Kunci: penyimpanan, pengemas, salak sidempuan, wafer

\begin{abstract}
Waste production of Salacca sumatrana Becc. reaches 31 to $43 \%$ per year or equivalent to 260 up to 310 tons per year. Biomass production can be potentially used as the alternative ration for ruminant species due to the feed sustainability. Study aims to evaluate the influence of different storage and the type of packaging materials on physical quality of wafer. Research conducted at laboratory of Feed Animal Industry, Faculty of Agriculture, Universitas Graha Nusantara Padang Sidempuan and Farmer Institution, Satahisaoloan Village. The research used completely random design with factorial $3 \times 4$ containing of 2 factors (packaging materials and storage rate) and 3 replications. Parameters of the research were physical quality including wafer weight, moisture content, wafer density and water activity $(A w)$. The results showed that the packaging material differently affected the physical quality of wafer feed. Meanwhile, the storage factor does not affect the physical performance of the wafer. The conclusion of the study is that the interaction of plastic bag packaging materials with a shelf life of 7 days gives better physical performance of the wafer.
\end{abstract}

Keywords: storage, packaging, salak sidempuan, waffer.

\section{Pendahuluan}

Tanaman salak (Salacca sumatrana Becc) merupakan spesies tanaman perdu dengan daun menyirip dan formasi bersatu dalam setiap pelepah utuh. Tanaman ini menghasilkan buah dengan deskripsi kulit yang menyerupai sisik ular. Oleh karena itu, buah salak ini dijuluki dengan sebutan snake fruits. Salah satu spesies tanaman salak yang cukup banyak dibudidayakan di Tapanuli Selatan yaitu salak Sidempuan. Salak Sidempuan tumbuh lebih tinggi dibandingkan dengan salak lainnya, seperti halnya salak pondoh. Selain itu, produksi pelepah dan daun lebih banyak meskipun seluruh permukaan pelepah memiliki duri yang sangat tajam. Selain menghasilkan buah, tanaman salak juga aktif 
memproduksi limbah sampingan seperti halnya dengan komoditi tanaman pertanian lainnya. Limbah tanaman salak dapat berupa pelepah, daun tua dan tandan buah kosong. Produksi limbah ini mencapai 31-43\% per tahun atau setara dengan 260-310 ton per tahun, sedangkan produksi limbah pelepah beserta daun tua mencapai $63.54 \%$ dari total produksi limbah yang dihasilkan [1]. Angka ini merupakan informasi penting untuk meningkatkan peluang pemanfaatan limbah tersebut. Seiring dengan ketersediaan lahan yang semakin sedikit, perkebunan dan perumahan (residentials) yang semakin meningkat, maka ketersediaan lahan untuk penanaman hijauan makanan ternak semakin menurun.

Sampai saat ini, peternak di Tapanuli Bagian Selatan (Tabagsel) masih mengandalkan rumput lapang dan pakan impor, namun upaya tersebut belum juga menunjukkan peningkatan produksi dari ternak yang dipelihara. Hal itu dibuktikan dengan data populasi ternak ruminansia yang terus menurun setiap tahunnya sampai $8 \%$ [1]. Ternak ruminansia yang dipelihara terdiri dari sapi, kerbau dan kambing. Kualitas rumput lapang yang diberikan kepada ternak belum memenuhi standar nutrien yang terkandung didalamnya. Selain kualitas, kuantitas rumput lapang juga menjadi persoalan serius. Peternak masih mengandalkan rumput liar dan sebagian dari hasil budidaya oleh peternak lokal. Situasi ini cenderung menyebabkan kenaikan terhadap biaya produksi khususnya dari aspek pakan ternak.

Penggunaan limbah agroindustri saja tidak cukup untuk memenuhi kebutuhan ternak, dibutuhkan pakan tambahan yang disusun dalam ransum seimbang menjadi pakan komplit untuk memenuhi kebutuhan akan zat makanan ternak. Salah satu teknologi yang dapat diterapkan dalam upaya meningkatkan kualitas mutu pakan, memudahkan penyimpanan serta dapat disimpan dalam waktu relatif lama yaitu dibuat dalam bentuk wafer. Pakan dijadikan dalam bentuk wafer dengan tekstur berbentuk segi empat sama sisi sehingga lebih efisien dalam pemberiannya kepada ternak. Wafer ransum komplit merupakan suatu bentuk pakan yang memiliki bentuk fisik kompak dan padat sehingga diharapkan dapat memudahkan dalam penanganan dan transportasi, di samping itu memiliki kandungan nutrisi yang lengkap, dan menggunakan teknologi yang relatif sederhana sehingga mudah diaplikasikan di lapangan. Wafer ransum komplit diformulasikan dengan kandungan nutrisi yang lebih lengkap sesuai dengan kebutuhan ternak, menggunakan bahan baku pakan yang murah dan tersedia dalam jumlah yang banyak.

Wafer pakan komplit dapat terjaga kualitasnya apabila disimpan dengan bahan pengemas yang baik. Pakan yang diolah tidak akan awet apabila tidak dilakukan penanganan lebih lanjut. Pengemasan merupakan salah satu cara pengawetan karena dapat memperpanjang umur simpan pakan tanpa menurunkan kualitasnya. Kemasan dapat membantu mencegah atau mengurangi kerusakan, melindungi bahan yang ada didalamnya terhadap cemaran serta gangguan fisik seperti gesekan, benturan dan getaran. Variasi pengemasan sangat menentukan perubahan fisik yang dialami oleh setiap pakan yang dikemas. Teknik dan proses yang dilalui selama pengemasan harus disesuaikan dengan kualitas bahan baku dan bahan pengemas yang digunakan. Bertolak dari kondisi potensi serta ketersediaan limbah tanaman salak dan ketergantungan peternak akan pakan lokal maka pengolahan limbah tanaman salak sebagai bahan baku utama dalam wafer ransum komplit dipandang akan sangat menjanjikan dalam penyediaan pakan di musim kemarau serta dapat menekan biaya produksi.

\section{Materi dan Metode}

\subsection{Waktu dan tempat penelitian}

Penelitian dilaksanakan pada bulan November 2018 sampai dengan bulan Desember 2019 yang berlokasi di Gudang pakan milik Kelompok Tani Satahisaoloan, Desa Simapilapil dan di Laboratorium Fakultas Pertanian, Universitas Graha Nusantara Padang Sidempuan.

\subsection{Alat dan bahan}

Alat yang digunakan dalam penelitian yaitu mesin chopper tipe AMPC1200, mesin kempa manual dengan beban dongkrak $100 \mathrm{~kg}$, timbangan analitik (kapasitas 1000 gram), bahan pengemas (plastik klip ukuran $1 \mathrm{~kg}$, karung plastik ukuran 30x25 dan wadah kardus ukuran 25X20x25 cm), terpal hitam ukuran 2X2 meter, oven, cawan porselen, alu dan lumpang, penggaris dan ember.

Bahan yang digunakan dalam penelitian yakni konsentrat limbah pelepah tanaman salak, bahan tambahan penyusun wafer (jagung halus, dedak padi, onggok, kalium bikarbonat [ $\left.\mathrm{CaCO}_{3}\right]$, molases, vitmin mix, garam dan urea).

\subsection{Alat dan bahan}

2.3.1. Proses pembuatan wafer berbasis limbah tanaman salak

Tahapan pembuatan pakan wafer berbasis limbah tanaman salak, yaitu:

a. Limbah tanaman salak dicincang dengan menggunakan mesin chopper, kemudian dikeringkan di bawah sinar matahari selama 3 hari dengan metode diangin-anginkan.

b. Proses penyortiran lidi yang terdapat di dalam konsentrat kasar limbah pelepah dan daun tanaman salak. Setelah dilakukan penyortiran, produk disebut dengan konsentrat limbah pelepah dan daun tanaman salak [KLPDS].

c. Proses pencampuran tahap 1; perekat (molases) dicampur dengan onggok, kemudian tahap 2; 
campuran tahap 1 dengan bahan penyusun ransum serta penambahan molases sesuai persentase yang ditentukan sampai mencapai titik homogen.

d. Hasil campuran tahap 2 dicampurkan kembali dengan KLPDS. Proses pencampuran dilakukan sampai homogen (terbentuk ransum wafer komplit berbasis limbah tanaman salak). Proses pencampuran dilakukan secara manual.

e. Produk hasil pencampuran dimasukkan ke dalam cetakan persegi yang terdapat dalam mesin kempa manual, kemudian dilakukan pengempaan manual dengan mengandalkan tekanan dari beban dongkrak $100 \mathrm{~kg}$ sampai pada titik kandas dongkrak.

f. Proses pengempaan dilakukan selama 5-10 menit. Produk wafer yang terbentuk dipindahkan secara perlahan ke atas nampan pengering untuk kemudian dibawa ke laboratorium (analisis lebih lanjut).

g. Wafer ransum komplit dikemas dengan berbagai bentuk pengemasan sesuai dengan desain lay-out perlakuan.

\subsubsection{Rancangan percobaan dan analisis data}

Rancangan percobaan yang digunakan dalam penelitian yakni Rancangan Acak Lengkap (RAL) pola Faktorial 4x3 dengan 2 faktor (A: bahan pengemas, B: lama penyimpanan) dengan 3 ulangan. Lay-out perlakuan yang digunakan adalah sebagai berikut:

\section{Faktor A: Ao: Tanpa pengemasan}

A1: Pengemasan dengan plastik

A2: Pengemasan dengan karung plastik

A3: Pengemasan dengan kardus

Faktor B: B1: Penyimpanan o hari

B2: Penyimpanan 7 hari

B3: Penyimpanan 14 hari

Kombinasi Perlakuan:

AoB1: wafer tanpa pengemasan dengan lama penyimpanan o hari

AoB2: wafer tanpa pengemasan dengan lama penyimpanan 7 hari

AoB3: wafer tanpa pengemasan dengan lama penyimpanan 14 hari

$\mathrm{A} 1 \mathrm{~B} 1$ : wafer dikemas dengan plastik dan lama penyimpanan o hari

A1B2: wafer dikemas dengan plastik dan lama penyimpanan 7 hari

$\mathrm{A}_{13}$ : wafer dikemas dengan plastik dan lama penyimpanan 14 hari

$\mathrm{A}_{2} \mathrm{~B}_{1}$ : wafer dikemas dengan plastik karung dan lama penyimpanan o hari

A2B2: wafer dikemas dengan plastik karung dan lama penyimpanan 7 hari
A2B3: wafer dikemas dengan plastik karung dan lama penyimpanan 14 hari

A3B1: wafer dikemas dengan kardus dan lama penyimpanan o hari

A3B2: wafer dikemas dengan kardus dan lama penyimpanan 7 hari

$\mathrm{A}_{3} \mathrm{~B}_{3}$ : wafer dikemas dengan kardus dan lama penyimpanan 14 hari

Data pengaruh perlakuan terhadap peubah yang diamati akan diuji dengan menggunakan analisis ragam atau analysis of variance (ANOVA) dan jika terdapat perbedaan nyata maka akan dilanjutkan dengan uji jarak Duncan dengan menggunakan program SPSS 17.

Tabel 1. Formula wafer ransum komplit dengan suplementasi limbah pelepah dan daun tanaman salak

\begin{tabular}{clc}
\hline No & Bahan Pakan & Persentase (\%) \\
\hline 1. & Jagung halus & 17 \\
2. & Dedak padi & 20 \\
3. & Onggok & 7 \\
4. & KLPDS & 40 \\
5. & Molases & 8 \\
6. & Vit-Min Mix & 2 \\
7. & Garam & 2 \\
8. & Urea & 1.5 \\
9. & CaCO & 2.5 \\
\hline Jumlah & 100 \\
\hline \multicolumn{3}{c}{ Protein Kasar* } \\
& Total Digestible Nutrients & 12.09 \\
& (\%BK)* & 75.83 \\
& Serat Kasar* & 18.68
\end{tabular}

Keterangan: ${ }^{*}$ Hasil formulasi yang disesuaikan dengan NRC (1994) dan Leeson and Summers (2005).

\subsubsection{Peubah yang diamati}

Parameter yang diamati dalam penelitian adalah:

a. Bobot awal wafer (gram)

Wafer yang hendak diteliti dilakukan pengukuran berat awal terlebih dahulu. Nilai berat awal wafer dapat menentukan gambaran perubahan kualitas fisik yang terjadi pada wafer selama proses penyimpanan.

b. Kadar air [2]

Kadar air diukur berdasarkan pedoman analisis proksimat. Nilai kadar air wafer ditentukan dengan menggunakan rumus:

$$
\text { Kadar Air }(\%)=\frac{(C+D)-\mathrm{E}}{D} \times 100 \%
$$

Keterangan: $\mathrm{C}=$ berat cawan porselen $(\mathrm{g}), \mathrm{D}=$ berat sampel (g) dan $\mathrm{E}=$ berat cawan + sampel setelah dikeringkan dalam selama 12-16 jam. 


\section{c. Kerapatan wafer}

Wafer pakan yang mempunyai kerapatan tinggi akan memberikan tekstur yang padat dan keras sehingga mudah dalam penanganan baik penyimpanan maupun goncangan pada saat transportasi dan diperkirakan akan lebih lama umur simpannya. Nilai kerapatan dihitung dengan menggunakan rumus:

$$
\mathrm{K}=\frac{W}{(P \times T \times L)} \times 100 \%
$$

Keterangan: $\mathrm{K}=$ Kerapatan $\left(\mathrm{g} / \mathrm{cm}_{3}\right), \mathrm{W}=$ Berat uji contoh (g), $\mathrm{P}=$ Panjang wafer uji (cm), L= Lebar wafer uji $(\mathrm{cm})$ dan $\mathrm{T}=$ Tebal wafer uji $(\mathrm{cm})$.

\section{d. Penyusutan}

Penyusutan merupakan proses kehilangan sebagian berat dari produk (pakan wafer) setelah diberikan perlakuan khusus. Persentase penyusutan wafer dihitung dari selisih berat wafer diawal perlakuan dengan berat akhir wafer setelah pengamatan dikali 100\%.

e. Daya serap air

Daya serap air (DSA) merupakan parameter yang menunjukkan kemampuan untuk menyerap air di sekelilingnya agar berikatan dengan partikel bahan atau tertahan pada pori antar partikel bahan [3]. Nilai DSA diperoleh setelah melakukan pengukuran berat sebelum dan sesudah perendaman pakan wafer ke dalam air selama 5 menit. Nilai DSA dapat dihitung dengan menggunakan rumus:

$$
\text { DSA }(\%)=\frac{\mathrm{BB}-\mathrm{BA}}{B A} \times 100 \%
$$

Keterangan: BA (Berat sebelum perendaman) dan BB (Berat setelah perendaman)

\section{Hasil dan Pembahasan}

\subsection{Bobot awal wafer}

Pengaruh perlakuan terhadap bobot pakan wafer dapat dilihat dalam Tabel 2. Berdasarkan analisis statistik, baik bahan pengemas yang bervariasi maupun lama penyimpanan yang berbeda tidak menunjukkan pengaruh nyata terhadap nilai berat awal pakan wafer penelitian.

Secara rataan, interaksi bahan pengemas dengan lama penyimpanan yang berbeda menunjukkan perbedaan rerata berat awal wafer khususnya pada umur penyimpanan 14 hari. Perbedaan yang ditimbulkan dapat dipengaruhi oleh komposisi pengacakan pakan wafer yang sangat variatif. Bobot awal wafer sangat identik dengan kualitas fisik awal pakan wafer sebelum pengujian. Selain itu, berat awal pakan wafer dapat digunakan untuk menentukan koefisien suatu proses penanganan, pengolahan dan penyimpanan. Bobot wafer yang semakin tinggi akan berpengaruh terhadap tingkat penyusutan dan kualitas nutrisi yang dikandungnya.
Tabel 2. Rataan bobot awal (gram) pakan wafer dengan bahan pengemas dan lama simpan

\begin{tabular}{|c|c|c|c|}
\hline \multirow{2}{*}{$\begin{array}{c}\text { Bahan } \\
\text { Pengemas }\end{array}$} & \multicolumn{3}{|c|}{ Lama Penyimpanan (hari) } \\
\hline & o & 7 & 14 \\
\hline \multirow[t]{2}{*}{ TK } & $439.18 \pm$ & $446.52 \pm$ & $456.13 \pm$ \\
\hline & $97.43^{\mathrm{a}}$ & $56.78^{\mathrm{a}}$ & $160.61^{a}$ \\
\hline \multirow[t]{2}{*}{ KP } & $433.48 \pm$ & $406.83 \pm$ & $389 \cdot 77 \pm$ \\
\hline & $107 \cdot 36^{\mathrm{a}}$ & $65 \cdot 54^{\mathrm{a}}$ & $43.25^{\mathrm{a}}$ \\
\hline \multirow[t]{2}{*}{ KK } & $446.15^{ \pm}$ & $405.88 \pm$ & $376.00 \pm$ \\
\hline & $72.18^{\mathrm{a}}$ & $85.83^{\mathrm{a}}$ & $48.86^{\mathrm{a}}$ \\
\hline \multirow[t]{2}{*}{$\mathrm{KD}$} & $450.63 \pm$ & $453.28 \pm$ & $430.77 \pm$ \\
\hline & $47 \cdot 45^{\mathrm{a}}$ & $63.44^{\mathrm{a}}$ & $52.01^{a}$ \\
\hline Sumber & \multirow{2}{*}{\multicolumn{2}{|c|}{ Probabilitas $(P)$}} & Keterangan \\
\hline \multicolumn{2}{|l|}{ Keragaman } & & \\
\hline Faktor A & \multicolumn{2}{|c|}{0.359} & $P>0.05^{\mathrm{TN}}$ \\
\hline Faktor B & \multicolumn{2}{|c|}{0.262} & $P>0.05^{\mathrm{TN}}$ \\
\hline Interaksi $\left(A^{*} B\right)$ & \multicolumn{2}{|c|}{0.180} & $P>0.05^{\mathrm{TN}}$ \\
\hline
\end{tabular}
yang berbeda.

Keterangan: $\mathrm{A}=$ Bahan pengemas pakan wafer, $\mathrm{B}=\mathrm{Lama}$ penyimpanan pakan wafer, $\mathrm{TK}=$ Tanpa pengemas, $\mathrm{KP}=$ Dikemas plastik, $\mathrm{KK}=$ Dikemas karung, $\mathrm{KD}=$ Dikemas kardus, $\mathrm{TN}=$ Tidak berpengaruh nyata

\subsection{Kadar air wafer}

Pengaruh perlakuan terhadap kadar air dapat dilihat pada Tabel 3. Berdasarkan analisis statistik, variasi lama penyimpanan menunjukkan pengaruh sangat nyata terhadap kadar air wafer, sedangkan faktor bahan pengemas yang berbeda dan interaksi tidak memberikan pengaruh nyata terhadap kadar air pakan wafer.

Tabel 3. Rataan kadar air (\%) pakan wafer dengan bahan pengemas dan lama simpan yang

\begin{tabular}{|c|c|c|c|}
\hline \multirow{2}{*}{$\begin{array}{c}\text { Bahan } \\
\text { Pengemas }\end{array}$} & \multicolumn{3}{|c|}{ Lama Penyimpanan (hari) } \\
\hline & o & 7 & 14 \\
\hline \multirow[t]{2}{*}{ TK } & $26.58 \pm$ & $26.38 \pm$ & $26.48 \pm$ \\
\hline & $8.44^{\mathrm{a}}$ & $10.68^{\mathrm{a}}$ & $8.42^{\mathrm{b}}$ \\
\hline \multirow[t]{2}{*}{ KP } & $18.27 \pm$ & $22.12 \pm$ & $29 \cdot 92 \pm$ \\
\hline & $6.16^{\mathrm{b}}$ & $2.46^{\mathrm{a}}$ & $6.65^{\mathrm{b}}$ \\
\hline \multirow[t]{2}{*}{ KK } & $20.00 \pm$ & $28.04 \pm$ & $32.60 \pm$ \\
\hline & $7.85^{\mathrm{a}}$ & $5 \cdot 52^{\mathrm{a}}$ & $10.14^{\mathrm{a}}$ \\
\hline \multirow[t]{2}{*}{$\mathrm{KD}$} & $15 \cdot 39 \pm$ & $23.94 \pm$ & $28.53 \pm$ \\
\hline & $3.98^{\mathrm{b}}$ & $2.88^{\mathrm{a}}$ & $9.71^{\mathrm{b}}$ \\
\hline Sumber & \multirow{2}{*}{\multicolumn{2}{|c|}{ Probabilitas $(P)$}} & Keterangan \\
\hline \multicolumn{2}{|l|}{ Keragaman } & & \\
\hline Faktor A & \multicolumn{2}{|c|}{0.545} & $P>0.05^{\mathrm{TN}}$ \\
\hline Faktor B & \multicolumn{2}{|c|}{0.006} & $P<0.01^{\mathrm{SN}}$ \\
\hline Interaksi $\left(A^{*} B\right)$ & \multicolumn{2}{|c|}{0.753} & $P>0.05^{\mathrm{TN}}$ \\
\hline
\end{tabular}
berbeda.

Keterangan: $\mathrm{A}=$ Bahan pengemas pakan wafer, $\mathrm{B}=$ Lama penyimpanan pakan wafer, $\mathrm{TK}=$ Tanpa pengemas, $\mathrm{KP}=$ Dikemas plastik, $\mathrm{KK}=$ Dikemas karung, $\mathrm{KD}=$ Dikemas kardus, $\mathrm{SN}=$ Berpengaruh sangat nyata, $\mathrm{TN}=$ Tidak berpengaruh nyata. 
Secara rataan, interaksi bahan pengemas yang berbeda dengan lama penyimpanan bervariasi lebih tinggi pada umur simpan 14 hari. Secara keseluruhan, wafer yang disimpan selama o sampai 14 hari menunjukkan perbedaan yang signifikan. Kadar air pakan wafer yang disimpan dengan plastik bening, karung plastik dan kardus mengalami peningkatan sampai umur simpan 14 hari. Kadar air pakan dapat dipengaruhi oleh kandungan air pada setiap bahan baku penyusun pakan wafer. Selain itu, profil suhu dan kelembaban ruang penyimpanan juga mempengaruhi kadar air pakan wafer. Peningkatan kadar air wafer khususnya dengan menggunakan bahan pengemas diduga mengalami peningkatan kelembaban. Semakin meningkat kelembaban dapat diketahui bahwa kadar air yang terkandung di dalam bahan cukup tinggi.

Suhu memiliki korelasi terbalik dengan laju kelembaban relatif. Semakin tinggi suhu dalam ruang penyimpanan, maka kelembaban relatif akan semakin rendah dan sebaliknya. Kelembaban relatif yang tinggi akan menyebabkan cairan terkondensasi ke permukaan sehingga permukaan pakan semakin kondusif untuk pertumbuhan mikroba seperti kapang. Pada penelitian, pakan wafer mulai ditumbuhi hifa kapang pada penyimpanan umur 7 hari. Dikaji dengan kadar air dalam pakan wafer yang cukup tinggi dibandingkan dengan kadar air standar yakni $\leq 15 \%$, kelompok mikroorganisme yang tumbuh pada pakan wafer merupakan golongan mesofil dan psikrofil. Hal ini diprediksi berdasarkan kisaran suhu ruang penyimpanan pada penelitian yakni $27-28$ oC. Hal ini sejalan dengan pendapat [4] yang menyatakan bahwa suhu ruang penyimpanan medium (27.40$28.16{ }^{\circ} \mathrm{C}$ ) sangat ideal untuk ditumbuhi mikroba mesofilik dan psikrofilik.

Kadar air sangat erat hubungannya dengan aktivitas air. Selain itu, struktur bahan penyusun wafer yang didominasi dengan golongan serat juga mempengaruhi kadar air pakan wafer. Komposisi bahan baku sumber serat menyebabkan terdapatnya rongga-rongga udara pada wafer, semakin banyak kandungan sumber serat maka rongga yang terdapat dalam wafer juga akan semakin banyak dan besar yang menyebabkan jalannya penguapan terjadi lebih cepat sehingga dapat meningkatkan kadar air yang terdapat dalam wafer. Pada umumnya bila aktivitas air dikurangi sampai batas tertentu akan menekan pertumbuhan dan perkembangan mikroorganisme [5]. Berbagai mikroorganisme mempunyai Aw minimum agar dapat tumbuh dengan baik, misalnya bakteri tumbuh pada Aw 0.90, khamir pada Aw 0.80o.9o, dan kapang pada Aw o.6o-0.70.

\subsection{Kerapatan pakan wafer}

Pengaruh perlakuan terhadap kerapatan wafer dapat dilihat pada Tabel 4. Berdasarkan analisis statistik, variasi lama penyimpanan dan bahan pengemas yang berbeda menunjukkan pengaruh tidak nyata terhadap kerapatan pakan wafer.

Tabel 4. Rataan kerapatan pakan wafer $\left(\mathrm{g} / \mathrm{cm}_{3}\right)$ dengan bahan pengemas dan lama simpan yang berbeda.

\begin{tabular}{|c|c|c|c|}
\hline Bahan & \multicolumn{3}{|c|}{ Lama Penyimpanan (hari) } \\
\hline Pengemas & o & 7 & 14 \\
\hline \multirow[t]{2}{*}{ TK } & $353.88 \pm$ & $443.95^{ \pm}$ & $482.10 \pm$ \\
\hline & $49.14^{\mathrm{a}}$ & $27 \cdot 38^{\mathrm{a}}$ & $72.52^{\mathrm{a}}$ \\
\hline \multirow[t]{2}{*}{ KP } & $348.33 \pm$ & $441.81 \pm$ & $467.08 \pm$ \\
\hline & $81.06^{\mathrm{a}}$ & $55.28^{\mathrm{a}}$ & $31.99^{\mathrm{a}}$ \\
\hline \multirow[t]{2}{*}{ KK } & $364.15 \pm$ & $429 \cdot 70 \pm$ & $366.21 \pm$ \\
\hline & $87.96^{\mathrm{a}}$ & $100.71^{\mathrm{a}}$ & $32.62^{\mathrm{a}}$ \\
\hline \multirow[t]{2}{*}{$\mathrm{KD}$} & $290.67 \pm$ & $375.82 \pm$ & $362.61 \pm$ \\
\hline & $21.37^{\mathrm{a}}$ & $66.99^{\mathrm{a}}$ & $170.84^{\mathrm{a}}$ \\
\hline Sumber & \multirow{2}{*}{\multicolumn{2}{|c|}{ Probabilitas $(P)$}} & Keterangan \\
\hline \multicolumn{2}{|l|}{ Keragaman } & & \\
\hline Faktor A & \multicolumn{2}{|c|}{0.256} & $P>0.05^{\mathrm{TN}}$ \\
\hline Faktor B & \multicolumn{2}{|c|}{0.057} & $P>0.05^{\mathrm{TN}}$ \\
\hline Interaksi $\left(A^{*} \mathrm{~B}\right)$ & \multicolumn{2}{|c|}{0.206} & $P>0.05^{\mathrm{TN}}$ \\
\hline
\end{tabular}

Keterangan: $\mathrm{A}=$ Bahan pengemas pakan wafer, $\mathrm{B}=\mathrm{Lama}$ penyimpanan pakan wafer, $\mathrm{TK}=$ Tanpa pengemas, $\mathrm{KP}=$ Dikemas plastik, $\mathrm{KK}=$ Dikemas karung, $\mathrm{KD}=$ Dikemas kardus, $\mathrm{TN}=$ Tidak berpengaruh nyata.

Secara rataan, interaksi pengemas dengan lama simpan pakan wafer menghasilkan nilai kerapatan berkisar 290.67- 482.10 g/cm3 dan masih lebih rendah dibandingkan dengan standar kerapatan wafer yakni $700-880 \mathrm{~g} / \mathrm{cm}_{3}$. Pengemasan dengan kardus menghasilkan kerapatan wafer yang sangat rendah dibandingkan dengan pengemas lainnya. Kardus memiliki struktur dan pori yang rapat sehingga menyebabkan laju kelembaban relatif yang sangat tinggi dibandingkan dengan pengemas lainnya. Dengan adanya kelembaban relatif yang tinggi maka aktivitas air akan semakin meningkat dan resiko kerusakan partikel penyusun wafer juga lebih tinggi.

Kerapatan berbanding terbalik dengan daya serap air, semakin tinggi kerapatan wafer menyebabkan kemampuan daya serap air semakin rendah. Namun, pernyataan tersebut tidak sesuai dengan hasil penelitian yang diperoleh. Kondisi tersebut diduga dipengaruhi oleh perbedaan kerapatan dari bahan baku wafer yang dipergunakan, sehingga mempengaruhi kerapatan wafer yang diperoleh pada penelitian ini. Selain sangat bergantung pada kerapatan bahan baku yang digunakan, kerapatan wafer juga sangat bergantung dengan besarnya tekanan kempa yang diberikan selama proses pembuatan. Wafer yang mempunyai kerapatan tinggi akan memberikan tekstur yang padat dan keras, sebaliknya wafer yang mempunyai kerapatan rendah akan memperlihatkan bentuk yang tidak terlalu padat, tekstur yang lebih lunak dan memiliki rongga-rongga. 


\subsection{Penyusutan wafer}

Pengaruh perlakuan terhadap penyusutan wafer dapat dilihat pada Tabel 5. Berdasarkan analisis statistik, bahan pengemas yang berbeda menunjukkan pengaruh nyata terhadap penyusutan wafer sedangkan lama simpan yang berbeda dan interaksi tidak memberikan pengaruh nyata terhadap penyusutan pakan wafer. Secara rataan, angka penyusutan yang lebih tinggi pada wafer dengan pengemasan menggunakan kardus baik pada umur o hari maupun 14 hari. Kadar penyusutan wafer penelitian berkisar $0.23-4.00 \%$. Nilai penyusutan wafer penelitian ini masih berada pada ambang batas minimum yakni di bawah $10 \%$ [6].

Tabel 5. Rataan penyusutan (\%) pakan wafer dengan bahan pengemas dan lama simpan yang berbeda.

\begin{tabular}{|c|c|c|c|}
\hline \multirow{2}{*}{$\begin{array}{c}\text { Bahan } \\
\text { Pengemas }\end{array}$} & \multicolumn{3}{|c|}{ Lama Penyimpanan (hari) } \\
\hline & o & 7 & 14 \\
\hline \multirow[t]{2}{*}{ TK } & $0.38 \pm$ & $0.31 \pm$ & $0.50 \pm$ \\
\hline & $0.14^{\mathrm{c}}$ & $0.20^{b}$ & $0.46^{\mathrm{b}}$ \\
\hline \multirow[t]{2}{*}{ KP } & $1.08 \pm$ & $0.56 \pm$ & $0.51 \pm$ \\
\hline & $1.41^{\mathrm{b}}$ & $0.47^{\mathrm{b}}$ & $0.25^{\mathrm{b}}$ \\
\hline \multirow[t]{2}{*}{ KK } & $0.38 \pm$ & $1.68 \pm$ & $0.29 \pm$ \\
\hline & $0.20^{c}$ & $2.12^{\mathrm{a}}$ & $0.24^{b}$ \\
\hline \multirow[t]{2}{*}{$\mathrm{KD}$} & $2.02 \pm$ & $0.23 \pm$ & $4.00 \pm$ \\
\hline & $2.37^{\mathrm{a}}$ & $0.21^{b}$ & $3.88^{\mathrm{a}}$ \\
\hline Sumber & \multirow{2}{*}{\multicolumn{2}{|c|}{ Probabilitas $(P)$}} & Keterangan \\
\hline \multicolumn{2}{|l|}{ Keragaman } & & \\
\hline Faktor A & \multicolumn{2}{|c|}{0.048} & $P<0.05^{\mathrm{N}}$ \\
\hline Faktor B & \multicolumn{2}{|c|}{0.616} & $P>0.05^{\mathrm{TN}}$ \\
\hline Interaksi $\left(A^{*} B\right)$ & \multicolumn{2}{|c|}{0.302} & $P>0.05^{\mathrm{TN}}$ \\
\hline
\end{tabular}

Keterangan: $\mathrm{A}=$ Bahan pengemas pakan wafer, $\mathrm{B}=$ Lama penyimpanan pakan wafer, $\mathrm{TK}=$ Tanpa pengemas, $\mathrm{KP}=$ Dikemas plastik, $\mathrm{KK}=$ Dikemas karung, $\mathrm{KD}=$ Dikemas kardus, $\mathrm{N}=$ Berpengaruh nyata dan $\mathrm{TN}=$ Tidak berpengaruh nyata.

Aktifitas fisik selama penanganan wafer dapat menimbulkan kerusakan pada tekstur wafer. Jenis aktifitas fisik dapat berupa benturan, tekanan berlebihan, dan penanganan lebih lanjut. Selain itu, cara dan bentuk pengemasan yang diaplikasikan juga mempengaruhi persentase wafer utuh. Terdapat berbagai pengujian yang dilakukan untuk menentukan kadar penyusutan wafer seperti halnya durabilitas produk. Nilai durabilitas juga mendukung pengukuran proporsi kehilangan (penyusutan) suatu produk.

\subsection{Daya serap air}

Pengaruh perlakuan terhadap daya serap air wafer dapat dilihat pada Tabel 7. Berdasarkan analisis statistik, bahan pengemas yang berbeda menunjukkan pengaruh nyata terhadap daya serap air wafer sedangkan lama simpan yang berbeda dan interaksi tidak memberikan pengaruh nyata terhadap daya serap air pakan wafer.

Tabel 6. Rataan daya serap air (\%) pakan wafer dengan bahan pengemas dan lama simpan yang berbeda.

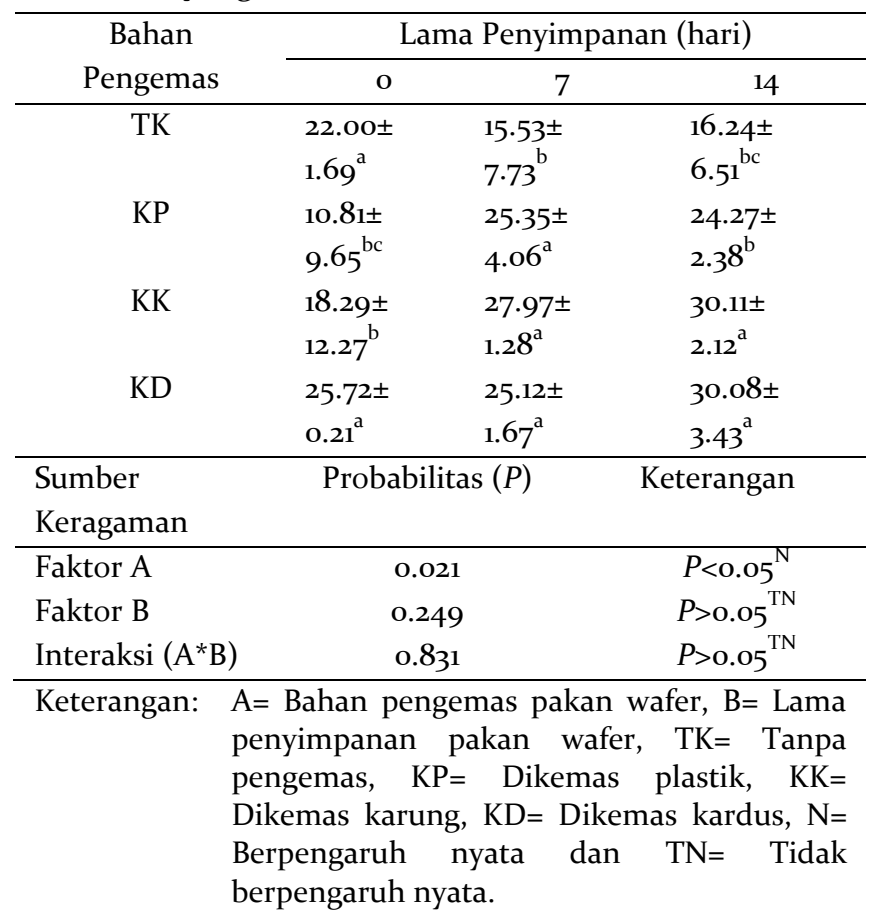

Secara rataan, wafer yang dikemas dengan karung, plastik, dan kardus mengalami peningkatan proporsi daya serap air seiring dengan penyimpanan yang semakin lama. Interaksi ini berbanding terbalik dengan wafer yang dikemas dengan kantong plastik dan kontrol (tanpa pengemas). Daya serap air merupakan parameter yang menunjukkan kemampuan untuk menyerap air di sekelilingnya untuk berikatan dengan partikel bahan atau tertahan pada pori antar partikel bahan [3]. Semakin tinggi daya serap air maka kelebihannya dalam mempermudah proses pencernaan secara fisik pada ternak akan lebih besar. Hal ini berdampak pada efisiensi saliva ternak untuk dapat melunakkan pakan wafer dan mempermudah proses mastikasi pada ternak.

\section{Kesimpulan}

Kesimpulan dari penelitian yakni penggunaan bahan pengemas yang berbeda untuk penyimpanan pakan wafer berbasis limbah pelepah tanaman salak mempengaruhi tingkat penyusutan dan daya serap air pakan wafer, sementara penyimpanan yang bervariasi tidak nyata mempengaruhi parameter fisik kecuali kadar air wafer dan wafer yang dikemas plastik dengan umur simpan 7 hari menunjukkan performa fisik wafer yang lebih baik dibandingkan dengan semua interaksi yang ada. 
Setelah dilakukan penelitian, disarankan bahwa:

1. Proses pengeringan udara terhadap wafer yang baru diperoleh dari proses pengempaan sebaiknya dilakukan dengan menggunakan oven sehingga diperoleh bobot kering udara yang seragam.

2. Wafer yang sudah dikering udara sebaiknya tidak ditumpuk sampai mencapai dingin yang konstan agar tidak menimbulkan pertumbuhan jamur (reaksi mikrobial).

\section{Referensi}

[1] Badan Pusat Statistik Tapanuli Selatan [BPS]. 2016. Statistik Produksi Tanaman Salak di Kabupaten Tapanuli Bagian Selatan. www.statistik komoditi salak di tapanuli selatan.com

[2] AOAC. 1984. Official Methods of Analysis Association of Official AnalyticalChemistry. The 4th Ed. Arlington, Virginia.

[3] Jayusmar. 200o. Pengaruh suhu dan tekanan pengempaan terhadap sifat fisik wafer ransum komplit dari limbah pertanian sumber serat dan leguminosa untuk ternak ruminansia. Skripsi. Fakultas Peternakan. Institut Pertanian Bogor, Bogor.

[4] Amiroh, I. 2008. Pengaruh wafer ransum komplit limbah tebu dan penyimpanan kualitas sifat fisik. Skripsi. Fakultas Peternakan. Institut Pertanian Bogor, Bogor.

[5] Florensyah, A. I. 2007. Pengaruh lama penyimpanan ransum komersial ayam broiler starter bentuk crumble terhadap kadar air, aktivitas air dan sifat fisik. Skripsi. Fakultas Peternakan. Institut Pertanian Bogor, Bogor.

[6] Dozir, W.A. 2001. Kualitas pellet pakan unggas pedaging (terhubung berkala). http://www.alabio.cjb.net. (5 Juli 2011). 